\title{
THE MICRO-FOUNDATIONS OF DUAL ECONOMY MODELS*
}

\author{
by \\ XIAOBING WANG \\ The University of Manchester \\ and \\ JENIFER PIESSE $\dagger$ \\ King's College London
}

\begin{abstract}
This paper provides microfoundations for dual economy models. First, the patterns of production and population growth in the traditional agricultural sector are examined. This shows the connection between long-run per capita income and subsistence wages. Second, it proves the existence of surplus labour and defines two types of surplus labour. Third, it considers two wage determination mechanisms in the modern sector and their relationships with the requirement for labour market restrictions. Fourth, the labour market is linked to food supply. Fifth, the dynamics of surplus labour and labour transfer are considered and two types of turning point are defined.
\end{abstract}

\section{INTRODUCTION}

One-sector growth models have dominated much of the recent literature on growth and development, but many development processes do not fit well into this framework. As Temple (2005) argues:

one-sector models cannot address the changes in employment structure, away from agriculture and towards manufacturing and services, which are currently under way on a vast scale in parts of the developing world ...

Lewis (1954) proposed a dual economy model characterized by the separation of the traditional agricultural sector from the modern industrial sector. ${ }^{1}$ Labour in the traditional agricultural sector is plentiful, frequently

* Manuscript received 2.6.10; final version received 4.1.11.

$\dagger$ The authors thank the editors of this journal, Keith Blackburn and Chris Orme, the anonymous referees, Ed Amann, Jeremy Clegg, Indranil Dutta, Fung Kwan, Xiaming Liu, Adam Ozanne, Paul Ryan, Roger Strange, Jonathan Temple, Tony Thirlwall, Bernard Walters, Nick Weaver and the seminar participates at a number of universities for valuable comments and suggestions, and especially Nick Weaver, with whom the many long discussions have helped to significantly improve this paper.

${ }^{1}$ It is necessary to clarify terms. The two sectors are different, not because they produce different products or are concentrated in different locations, but because they have different objectives and organizational models. In this sense, not all agriculture is traditional, nor is it all based on the subsistence mode. Not all the subsistence sector outputs are agricultural, nor the modern sector industrial. In two-sector theoretical models, large-scale commercial agriculture has been classified as part of the capitalist industrial sector, and the term agriculture is applied to the whole non-capitalist sector. To be precise, the labels subsistence 
having a zero marginal productivity, while in the modern sector labour has a positive marginal product. There is an income gap between the two sectors and rural surplus labour in the traditional sector has an incentive to move to the modern sector. The population in the traditional sector is sufficiently large that there is an unlimited supply of labour able to move to the modern sector at a subsistence wage in a given period without lowering output. This unlimited supply of labour from the traditional sector keeps wages in the modern sector low, ensures that capital accumulation in the modern sector is sustained over time, and thus leads towards economic transformation.

It has been more than 50 years since the publication of Arthur Lewis' seminal paper in The Manchester School in 1954. This paper can be considered to be the starting point of development economics and has generated a substantial theoretical and empirical literature of which a large part is as extended commentary on the meaning and ramifications of the ideas set out in that paper (Findlay, 1980, p. 64). ${ }^{2}$ It is 'widely regarded as the single most influential contribution to the establishment of development economics as an academic discipline' (Kirkpatrick and Barrientos, 2004).

However, although the general framework of the Lewis dual economy model is insightful the fundamental concepts and micro-mechanisms, especially the definition of surplus labour, the wage determination mechanisms in both the traditional and modern sectors and the dynamics of labour flows between the two sectors lack sufficient detail and are still unclear (Brown, 2006; Fields, 2006). ${ }^{3}$ This lack of a micro-foundation has been a barrier to further development of the model and prevented it from being used rigorously in empirical research. ${ }^{4}$

This paper retains the essence of the Lewis model but extends it in order to provide a conceptual review to clarify the issues and establish the necessary micro-foundations to dual sector models. It is organized as follows. The next section reviews the characteristics of a traditional agricultural economy. Section 3 defines the concept of surplus labour and Section 4 discusses the

and capitalist would be more accurate, because they imply the output level in the former sector is at subsistence level, and the latter sector is for profit, which suggests that the wage in the capitalist sector must be no higher than workers' marginal contribution. However, much dual economy literature does not distinguish these, but uses them interchangeably. In this paper, for simplicity, except in the section discussing special issues, the traditional sector is agricultural and is subsistence, and the modern sector is mostly nonagricultural. Therefore, terms such as subsistence, traditional, rural, and agricultural, noncommercialized, non-capitalized sector are used interchangeably, unless otherwise stated. The same applies to modern, urban, non-agricultural, industrial, manufacturing, commercialized and capitalist sector.

${ }^{2}$ The Manchester School published two special volumes (Vol. 47 No. 3 and Vol. 72 No. 6) in 1979 and 2004, on the 25th and 50th anniversaries of the publication of Lewis' paper, which provide reviews of the development of the dual economy model over the last 50 years.

${ }^{3}$ This lack of clarity was also true for Lewis himself. For example, his 1954 and 1979 papers differ in some important respects.

${ }^{4}$ Leeson $(1979$, p. 200) argues that '. . . Lewis declares himself in favour of realism as against precision in the formulation of his model'. 
wage determination mechanism in the traditional sector. The next section defines two different wage determination mechanisms for the modern capitalist sector. Section 6 presents three stages of labour transfer and two turning points based on the concept of two types of surplus labour. Section 7 considers the role of agriculture and food supply. Section 8 studies the dynamics of surplus labour and its relationship to technical change in the traditional sector. Section 9 considers the dynamics of labour transfer, and factors that affect it, such as capital accumulation and technological change. Section 10 concludes.

\section{The Traditional Agricultural Economy}

This section examines the characteristics of the traditional economy. A closed traditional agricultural economy is assumed, which is at an early stage of development with no surplus arable land. This traditional agricultural society mainly consists of family units engaged solely in agricultural production. All family members share the work and the subsequent output, either as wages or as profits. ${ }^{5}$ No family members are denied food, i.e. the intra-family distribution principle is sharing and benefits are spread equally. Thus, no family member is unemployed and each earns the average product of labour in the agricultural sector, APL, as noted by Lewis (1954), Fei and Ranis (1964, 1997), Sen (1967) and Fields (2004). ${ }^{6}$

Next, the equilibrium quantity of the average product of labour and population level are considered. At its long-run equilibrium, population growth is as described by Malthus (1798): in this economy population growth

${ }^{5}$ Two issues need to be clarified. First, not all the population engages in production, but for simplicity the population is assumed to equal the labour force. Second, labour is used for convenience although the number of workers and hours worked should be differentiated and labour defined in terms of man-hours rather than individuals. This involves the concepts of dynamic and static surplus, i.e. the dynamic surplus takes the form of a low number of hours worked. If people leave the land, those remaining must work longer or harder to compensate. However, to avoid unnecessary complications, this paper does not distinguish between the two. Thus the marginal product of labour (MPL) can be seen as the product of the marginal man-hours applied in agriculture or industry.

${ }^{6}$ Kirkpatrick and Barrientos (2004) and Colman and Nixson (1994) describe this well:

In the initial stage, labour in the traditional sector is not therefore remunerated in line with its marginal productivity. In the case of family farms, members may share their output equally, and 'wages' correspond to average productivity per person (Sen, 1966). Even where a 'wage' is paid, for example, to domestic servants, it has at best a weak link to marginal productivity as 'in overpopulated countries the code of ethical behaviour so shapes itself that it becomes good for each person to offer as much employment as he or she can. The line between employees and dependents is very thinly drawn' (Lewis, 1954, p. 142). (Kirkpatrick and Barrientos, 2004, p. 685).

Such a situation can occur where the system of land tenure grants some land-use rights to every family and where each family subsists by sharing out among its members the products of the family holding. Under this system, agriculture forms a sink in which everybody not supported by employment industry can find a livelihood, and it enables non-productive family members to consume at the level of the average product per person. (Colman and Nixson, 1994, p. 37) 
is viewed as being a natural process beyond family control. Population adjusts until all individuals are at the subsistence level of consumption. ${ }^{7}$ Historical evidence supports the Malthusian hypothesis, as up until the last 200 years the population grew very slowly, despite a biological potential for very rapid growth (Kremer, 1993).

Thus the following theorems can be stated.

Theorem 1 (Malthusian relationship): In the traditional economy, the equilibrium population level, $\bar{P}$, is given at the point where the average product of labour (per capita income) is equal to the subsistence level of income $\bar{y}$, i.e. $\mathrm{APL}=\bar{y}$.

Because of diminishing returns to labour, when land is fixed and more people enter the sector, the marginal product of labour, MPL, will decrease, and therefore so does the average product of labour. ${ }^{8}$ The long-run population level adjusts as a function of available food. ${ }^{9}$

This Malthusian population growth theory illustrates the relationship between the average product and the subsistence wage in the traditional

${ }^{7}$ Because population growth rate depends on the availability of food, the Malthusian forces tend to lock closed agrarian systems into long-run stagnation (Fei and Ranis, 1964, 1997, pp. 51-55). This effect was also explained in Jorgenson $(1961,1966)$, as described in Fei and Ranis (1997, p. 54):

it is frequently argued that initial productivity gains in agriculture lead to upward revision of the consumption standard or wage. If the gains are used entirely for consumption adjustment, then the Jorgenson classical thesis of stagnation applies.

${ }^{8}$ It is worth noting that the marginal product results from the loss of output by withdrawing a unit of labour and not the marginal contribution of that labourer when employed.

${ }^{9}$ As Lewis (1954, p. 189) noted:

The subsistence wage . . may be determined by a conventional view of the minimum required for subsistence; or it may be equal to the average product per man in subsistence agriculture, plus a margin.

It is safe to assume that what Lewis claims to be the minimum required for subsistence is the level of subsistence in the Malthusian sense. Either the Lewis subsistence wage and the Malthusian subsistence wage are identical or there is a mark-up between the two. If they are identical, the Lewis subsistence level of consumption is a biologically determined constant. The level of consumption can be easily extended to be not determined biologically, but by preferences and technology. The essences of the Lewis model holds in both cases. Of course, the subsistence wage level evolves with time-i.e. it can meet the minimum cost of living, but is not necessarily the wage that only meets the minimum cost of survival. Rather, it keeps up with time and development. However:

The notion of a subsistence minimum is, of course, not without ambiguity. To the bare biological minimum necessary for work is to be added something to facilitate the reproduction of the work force, the feeding and clothing of the workers family. And there is an element of customary rather than biological necessity which renders the concept very hazy. The contribution of early development economics was to define the subsistence minimum in terms of the alternative available to the worker i.e. the living standard of the members of the subsistence sector. (Leeson, 2008, p. 31)

For simplicity, the latter is ignored. Of course, even in the situation where there is a mark-up above the biologically determined level of consumption, that is still a conventional view of the minimum required for subsistence. 


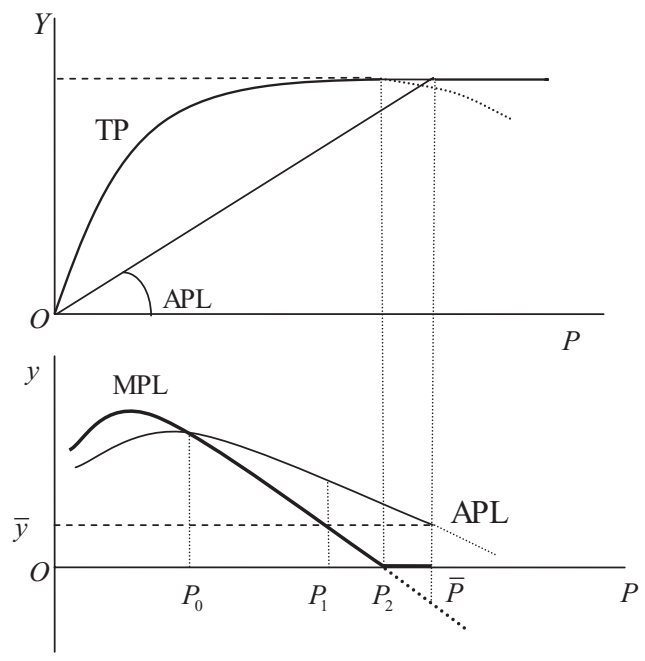

FIG. 1. Output and Labour

sector. Now the subsistence wage, $w_{\mathrm{s}}$, has to be equal to the subsistence level of output per head, $\bar{y}$, in equilibrium.

Now if $w_{s}=\mathrm{APL}=\bar{y}$, there exists a labourer, $i$, for whom $w_{i}=\mathrm{APL}=\bar{y} \geq \mathrm{MPL}_{i}$.

Theorem 2 (Existence of surplus labour): In the traditional economy where labour is paid the APL, there exists surplus labour (such surplus labour being defined as those workers who are paid higher than their MPL).

Figure 1 illustrates the existence of surplus labour. For both the top and bottom figures, the horizontal axis, $O P$, shows the population in the economy. In the top the vertical axis is total output, $Y$. Given a fixed amount of land, total output (increasing and concave) is determined by a change in population, $P$. In the bottom figure, the MPL curve is the marginal product of labour (MPL is the tangent to curve TP, in the top figure) and the APL curve is the average product of labour in the traditional sector. $\bar{y}$ is the subsistence level of output per capita, and is also the average product of labour in the steady state (in the Malthusian equilibrium). As stated above, the equilibrium population level in the traditional agricultural society is at $\bar{P}$, where $\mathrm{APL}=\bar{y}$. That is, $\bar{P}$ is total population in the steady state. In the figure $\bar{P}-P_{2}$ is the amount of labour where MPL is equal to or less than zero.

\section{Surplus Labour Further Defined}

This section clarifies the various definitions of surplus labour. The simple definition implies the existence of a point at which the marginal product of 
labour becomes zero and labour can be transferred out of the traditional sector without reducing the quantity of output, as noted by Wellisz (1968, p. 22):

The (disguised-unemployment or the Unlimited Supply of Labour) hypothesis claims that in poor, densely populated countries, more people are employed than needed to produce the prevailing output with the existing techniques and the existing supply of non-labour inputs. The 'surplus' labour constitutes 'hidden' or 'disguised' unemployment. Many of the proponents of the hypothesis make the further claim that agricultural output will not decrease, and industrial output will increase, if measures are taken to re-allocate labour from subsistence agriculture (where the surplus is supposed to exist) to industry (where there is no surplus labour). Since labour can be removed from agriculture at no social cost, its supply to industry is, in a sense, 'unlimited' as long as disguised unemployment prevails.

However, Ranis (2008) does not agree, preferring to regard those whose marginal product lies below their consumption or income share as surplus labour, or more specifically, as disguised unemployed or underemployed. Ranis defines surplus labour as follows:

The basic premise is that there exist some sectors or sub-sectors in which, in the presence of a large endowment of unskilled labour and the absence of sufficient cooperating land or capital, with a given technology and a wage level bounded from below, labour markets cannot clear. A full employment, neoclassical 'wage equals marginal product' solution would drive remuneration below socially acceptable, possibly subsistence, levels of consumption. Consequently, a labour surplus exists in the sense that a substantial portion of the labour force contributes less to output than it requires, i.e., its marginal product falls below its remuneration, set by bargaining. (Ranis, 2008, p. 1)

\section{Lewis (1954, p. 141) provides a general definition that:}

an unlimited supply of labour may be said to exist in those countries where population is so large relatively to capital and natural resources, that there are large sectors of the economy where the marginal productivity of labour is negligible, zero, or even negative.

Clearly, as noted by Lewis, both these circumstances exist, so it is useful to distinguish these two types of surplus labour: labour with positive but negligible marginal productivity, and labour with zero, or even negative marginal productivity. This distinction will have important implications in the wage determination mechanisms in the modern sector, which will be discussed later.

Definition 1: Labour is defined as type I surplus labour (absolute surplus labour) if the MPL is equal to or less than zero, i.e. when MPL $\leq 0<w_{\mathrm{s}} \leq w$, where $w$ is the real wage of a labourer.

Labour is defined as type II surplus labour (relative surplus labour) if the MPL is greater than zero but lower than the actual wage received, i.e. when $0<$ MPL $<w$. 
The definition of type II surplus labour states that, as long as $0<\mathrm{MPL}$ $<w$ holds, it is irrelevant whether MPL is lower or higher than the subsistence level (MPL $<w_{\mathrm{s}}$ or MPL $>w_{\mathrm{s}}$ ), although it is assumed to be lower than the subsistence level $\left(\mathrm{MPL}<w_{\mathrm{s}}\right)$.

Note that surplus labour also includes unutilized labour, including those not participating in production in the neoclassical sense. Labour can be considered to be surplus even if they are unemployed. That is, were they to work, their MPL would be small, zero or negative. In fact, such individuals may remain idle rather than participating in the workforce, although the assumption here is that they are provided for by other family members. Their marginal utility of leisure is also zero as it is infinitely abundant and they could be put to work at subsistence wages. For example, in the traditional agricultural economy, certain tasks may require all family members to work one-fifth of their time, or only one-fifth of the members to work full-time. Surplus labour exists in this sense. ${ }^{10}$

\section{Wage Dynamics in the Traditional Sector}

Now consider how the wage in the traditional agricultural sector changes in the presence of labour transfer. When workers are drawn out of the traditional sector into the modern capitalist sector those who remain enjoy higher average output and thus receive a higher income than before, in the absence of population growth or when the transfer outweighs any population increase. ${ }^{11}$

Assume $w_{\mathrm{a}}$ is the wage in the traditional agricultural sector. There is surplus labour with MPL smaller than $w_{\text {a }}$ that would have been unemployed if the neoclassical model was applied to the agricultural sector, but are now underemployed with a wage higher than their MPL. The removal of labour has raised the standard of living of the remainder, simply because the same output is now spread over a small labour force. This is true for both type I and type II surplus labour.

Proposition 1: The wage in the subsistence sector increases when type I and/or type II surplus labourers move out, although type I surplus labour makes no marginal contribution, in the absence of population growth or when the transfer outweighs population increase.

\footnotetext{
${ }^{10}$ In neoclassical terms, this is involuntary unemployment. Workers' marginal utility of leisure is very low and they are unable to find work at the subsistence wage level. A job paying below subsistence level is not feasible in the neoclassical framework.

${ }^{11}$ One may argue that if the traditional sector is so big and the modern sector is so small that there is hardly any impact on the average productivity in the traditional sector when small-scale migration takes place. However, non-measurable, or negligible increases in APL do not mean no increase.
} 
However, population will adjust according to the Malthusian theorem preventing the APL in the subsistence sector from rising. That is, if the rate of migration and the rate of population increase is the same, Malthusian population growth will replace all the surplus labour that has moved to the modern sector and the APL will not change. This will be revisited in the section on labour dynamics.

\section{Wage Determination Mechanisms in the Modern Sector}

While the determination of the real wage in the modern sector is at the core of the Lewis model (Fields, 2004), Lewis $(1954,1972,1979)$ is unclear on the mechanisms at work (Fields, 2006). It is one of the main issues in the important debate between Fields (2006) and Brown (2006). This section sets out the conditions for the existence of two mutually contradictory mechanisms in the dual sector models and their relationship with the unlimited supply of labour.

The first mechanism is the one proposed in Lewis (1954) and is a Harris and Todaro (1970) type mechanism.

Definition 2: Wage Determination Mechanism I: the real wage in the modern sector is determined by the real wage in the traditional sector and 'Anything which raises the productivity of the subsistence sector (average per person) will raise real wages in the capitalist sector' (Lewis, 1954, p. 172).

The second mechanism, which supports labour market segmentation (e.g. Fields, 2004), is as follows. This reflects Fei and Ranis's (1964) elaboration of the Lewis model and subsequent work by others including Lewis himself (1979).

Definition 3: Wage Determination Mechanism II: the modern capitalist sector wage is set above the competitive wage level ${ }^{12}$ and is not determined by productivity/wage level in the traditional subsistence sector.

The distinction between the two mechanisms is that, while in Mechanism II the wage in the modern sector is independent of that in the traditional sector, in Mechanism I they are correlated. Thus, an interesting issue is why these two mechanisms are contradictory. Fields (2006, p. 356) explains:

\footnotetext{
${ }^{12}$ This is typically influenced by a combination of institutional forces, including unions, any minimum wage legislation and public sector pay policy and also here by implication we are assuming that these are not heavily influenced by the traditional sector's wage. 
either (i) the wage in the formal sector is institutionally fixed, meaning that it is a function only of institutions and not other things, or (ii) the wage in the formal sector is a function of subsistence sector productivity. It cannot be both. ${ }^{13}$

In Mechanism I, the modern sector wage is determined by the wage in the traditional sector. Following Todaro (1969) and Harris and Todaro (1970), $u$ is the modern sector unemployment rate, $(1-u)$ is then the probability of finding a modern sector job, giving a new labour market equilibrium condition $(1-u) w_{\mathrm{I}}=w_{\mathrm{A}}$, where $w_{\mathrm{I}}$ is the wage in the modern industrial sector and $w_{\mathrm{A}}$ is the wage in the traditional agricultural sector (equals to the subsistence level $w_{\mathrm{s}}$ ). Although the modern sector wage is nominally higher, the actual wage is equal after being deflated by unemployment.

So now, because $w_{\mathrm{I}}(t)=w_{\mathrm{A}}(t) /(1-u)$ and, when $u$ is kept constant, $w_{\mathrm{I}}(t)$ will increase if $w_{A}(t)$ increases, and the two are equal when $u$ is zero. The increase in the subsistence wage in the traditional agricultural sector increases the wage in the modern sector. As Brown (2006, p. 352) claims:

the earnings differential between the two sectors is not attributable to a segmented labour market, but simply to the costs (for Lewis, both real and perceived) of moving from the traditional to the modern sector. After allowing for cost differences, there might be no effective real wage differential. Although the labour force in the original Lewis model is divided between the two sectors of the economy, there was no segmentation or labour market dualism in terms of restrictions on the entry of labour into the formal from the informal sector.

In this case, there is no real wage difference, the two sectors have identical real wages (after adjustments), and any wage increase in the agricultural sector will increase the real wage in the modern sector. There would not then be an unlimited supply of labour to the modern sector at a constant wage rate if the population is not growing. This is because when there is no population growth, if surplus labour moves out of the agricultural sector, wages in that sector will increase and if wages in that sector increase, wages in the nonagricultural sector will also increase. Therefore:

Proposition 2: There is no unlimited supply of labour (at a constant wage rate for a period of time) under Wage Determination Mechanism I, even in the circumstance that the traditional sector has a stock of type I (absolute) surplus labour and type II (relative) surplus labour, given the population in the economy is constant.

\footnotetext{
${ }^{13}$ One might argue that Fields is not correct here and that the institutions determining the wage are themselves influenced in this process by the productivity of the traditional sector. But one could argue that the distinction between 'determination' and 'influence' is what is at issue. Indeed it can be argued that where wages are set as per Mechanism I this is just another case of an institutionally determined wage; and this is more precisely what Lewis meant by institutional determination.
} 
Proposition 2 takes a static view. ${ }^{14}$ However, there can be unlimited supply of labour although at a constant wage, under Wage Determination Mechanism I, if population growth in the traditional sector keeps the stock of surplus labour in that sector unchanged when some existing surplus labour moves out. As discussed previously, in the long run, when the APL is higher than the subsistence level, population in the traditional sector will grow. The entry to the traditional sector would be equal to the number of people who moved out. In a dynamic sense, an unlimited supply of labour for the modern sector can be said to exist. Thus:

Proposition 3: There can be an unlimited supply of labour (at a constant wage rate for a period of time) under Wage Determination Mechanism I, if emigration to the modern sector happens slowly, which allows a dynamic population adjustment to take place..$^{15}$

Now to return to Mechanism II. If the equilibrium wage rate in the modern sector is defined as $w_{\mathrm{e}}=\left[w_{\mathrm{I}}(1-u)-c_{\mathrm{m}}\right] /(1+\xi)$, where $w_{\mathrm{e}}$ is the equilibrium wage rate in the modern sector, $c_{\mathrm{m}} \geq 0$ is the cost of migration, $\xi \geq 0$ is the proportionally higher living costs in the capitalist urban sector. ${ }^{16,17}$ Here $w_{\mathrm{e}}$ expresses the modern sector real wage deflated by unemployment, migration costs and higher living costs in the modern sector, such as pollution, distance from family etc.

If the wage is determined by Mechanism II, the modern sector wage being institutionally set at a higher level than the traditional sector wage, 'Earnings in the subsistence sector set a floor to wages in the capitalist sector, but in practice wages have to be higher than this' (Lewis, 1954, p. 150), and 'different wages are paid to comparable workers' (Lewis, 1954, pp. 148-149). In this case, the wage in the modern sector is set independently of the

${ }^{14}$ This is illustrated by Leeson (1979, p. 198):

... labour transfer would result in a rising average income amongst the remaining sectoral member, and hence the logic of the model ought to indicate a rising labour supply price right from the start.

${ }^{15}$ Lewis $(1979$, p. 218) believes that 'population growth is at the core of labour abundance'. Leeson (1979, p. 200) explains, '. . population growth in the subsistence sector helps to negate the rise in incomes...'

${ }^{16}$ The equilibrium wage, $w_{\mathrm{e}}$, is introduced to rule out the possibility that sometimes, although the modern sector wage, $w_{\mathrm{I}}$, is higher than $w_{\mathrm{A}}$, it is also a subsistence wage. In this case, only the modern sector subsistence wage (the nominal wage), $w_{\mathrm{I}}$, is higher than the traditional subsistence wage, $w_{\mathrm{A}}$, while after adjusting for modern sector unemployment, migration costs and living cost, the deflated modern sector wage, $w_{\mathrm{e}}$, is the same as the rural subsistence wage, $w_{\mathrm{A}}$. So, even if workers in both sectors are living at a subsistence level, the modern sector wage level may be higher than that of the rural. That is why the real comparable wage, $w_{\mathrm{e}}$, not the nominal wage, $w_{\mathrm{l}}$, is used in comparison.

${ }^{17}$ These migration costs can result from credit market barriers. The funds involved may be modest but because of the underdeveloped rural credit markets those who would have migrated still have no means of raising the migration costs and hence are locked into the rural areas and a poverty trap. 
traditional sector; ${ }^{18}$ even after all the cost adjustment, there are some real wage differences between the two sectors, $w_{\mathrm{e}}(t)>w_{\mathrm{A}}(t)$. The increase in $w_{\mathrm{A}}$ will reduce the gap between the sectors but will not necessarily affect $w_{\mathrm{e}}$, given that the wage rate in the modern sector was not set as a fixed rate above the traditional wage rate. So, the modern capitalist sector still faces an unlimited supply of labour, until the turning point $w_{\mathrm{e}}(t)=w_{\mathrm{A}}(t)$ is reached. Before this point, $w_{\mathrm{A}}$ approaches $w_{\mathrm{e}}$.

Proposition 4: There is unlimited supply of labour (at a constant wage rate) under Wage Determination Mechanism II until the turning point is reached, where $w_{\mathrm{e}}(t)=w_{\mathrm{A}}(t)$, with or without population growth in the traditional sector.

If a different wage is paid to identical workers in different sectors, ${ }^{19}$ however, there must be labour market segmentation in the form of restrictions on entry by labour from the traditional into the modern capitalist sector. Otherwise, labour will migrate to gain a higher wage. In this case, barriers must exist to prevent labour moving from the traditional to the modern sector to maintain labour market segmentation. ${ }^{20}$ This can either be institutional segmentation, such as government policy restrictions on migration, labour unions and even efficiency wages, or be other natural barriers to migration, such as low education levels, lack of information about the modern capitalist sector, physiological costs etc.

Thus, it is possible to explain Lewis' $(1954$, p. 150) claims: 'there is usually a gap of 30 per cent or more between capitalist wages and subsistence earnings'. The gap can be composed by cost factors or by real labour market barriers or both. In a real economy, many factors are hard to remove and result in labour market segmentation. However, to study the development process theoretically, we have to assume a simplified world without entry barriers, without labour market segmentation, which means the modern sector real wage is the same as the real wage level in the traditional sector.

${ }^{18}$ Of course, as noted above, this 'independency' should not be taken literally. Although the institutionally determined wage is not set at the market clearing level, it is possible that the institutional mechanisms at work are influenced by changes in the traditional sector wage. That is, the institutional wage may take account of and be influenced by what is happening to wages elsewhere in the economy. For instance, if earnings rise in the traditional sector this could allow the unions to negotiate higher wages in the modern sector.

${ }^{19}$ As Lewis $(1979$, p. 211$)$ put it, ' . . . unskilled labour is paid more in the modern sector than in the traditional sector for the same quantity and quality of work'.

${ }^{20}$ The labour market segmentation here means the segmentation between the traditional and the modern sector. However, Lewis (1979) examines segmentation within the modern sector, which enables him to retain the important assumption that, for most modern sectors, wages were determined by the average product of labour in the traditional sector, while for others - the 'labour aristocracy' - wages increased with productivity in the modern sector. However, this did not solve the puzzle of how the same quantity and quality of work can be paid more in the modern sector than in the traditional sector, which is the focus of this paper. 
Proposition 5: If there is no institutional barrier and/or market segmentation, the adjusted real wage in the modern sector, $w_{\mathrm{e}}$, would be equal to the subsistence level in the traditional sector, $w_{\mathrm{A}}$.

Proposition 6: Under Wage Determination Mechanism II, if $w_{\mathrm{I}} \geq w_{\mathrm{e}}=w_{\mathrm{A}}$, no labour market segmentation is needed; if $w_{\mathrm{I}} \geq w_{\mathrm{e}}>w_{\mathrm{A}}$, market segmentation is needed to maintain higher wages in the modern sector.

This means that labour market segmentation is a necessary condition for a constant higher wage in the modern sector whereas if there is no segmentation, Mechanism I will prevail. This is common in the early stages of development where labour is withdrawn from the traditional sector consistently but at a very slow rate, so that population growth is able to adjust and make up for the amount of labour emigration from the traditional sector. Hence, the modern sector can withdraw labour from the traditional sector and still retain subsistence wages.

\section{Two Turning Points and Three Stages of Labour Transfer}

Fei and Ranis $(1964,1997$, p. 120) define three stages of labour transfer in terms of an institutional real wage (IRW) which for them represents consumption of food per labourer.

Stage I: MPL $=0<$ IRW

Stage II: $0<$ MPL $<$ IRW

Stage III: $0<$ IRW $<$ MPL

Fei and Ranis (1997, pp. 120-121) explain that:

in stage I there exists disguised unemployment with labour redundancy, in stage II there exists disguised unemployment with labour non-redundancy, and in stage III the disguised unemployment has disappeared completely. . . . labour release proceeds through the three stages in the given order.

Their definitions involve an institutional real wage. However, as was made clear in the wage determination mechanism section above, the subsistence level of wages may not be determined by institutional factors (Wage Determination Mechanism II), but by market competition (Wage Determination Mechanism I). So the IRW might be usefully replaced with the more general concept, the subsistence level of wage, $w_{\mathrm{s}}$, in this discussion.

The three stages can now be rewritten as:

Definition 4: Three stages of labour transfer can be defined as follows: stage I is when there exists type I (absolute) surplus labour; stage II is when there only exists type II (relative) surplus labour. Stage III is when there is no surplus labour. 
After defining two types of surplus labour and three stages of labour transfer, the two turning points, which divide the three stages, can be stated: ${ }^{21}$

Definition 5: A type I turning point is defined as one when type I (absolute) surplus labour is exhausted (MPL approaches a positive value), and a type II turning point as one when type II (relative) surplus labour is exhausted (MPL approaches the real wage they get paid).

In the first stage, when there is an unlimited supply of labour, the modern sector wage is constant. Then when all type I surplus labour is absorbed by the modern sector, the economy passes a type I turning point and enters stage II. In stage II the modern sector wage starts to increase. When type II surplus labour has been exhausted, the economy passes a type II turning point into stage III. After entering stage III the wage in the traditional sector also begins to increase. This is the point when the traditional sector starts to compete for labour with the modern sector at a rate that is determined by neoclassical demand and supply principles. The economy now can be modelled by a neoclassical one-sector theory.

\section{The Role of Agriculture and Food Supply}

This section discusses the role of agriculture and the food supply in the development process. In the discussion so far, the traditional-to-modern sector migration of surplus labour has been limited only by demand. However, when people move out of the traditional agricultural sector, they have to consume agricultural products to survive. That is, the traditional-tomodern sector migration might be limited by the supply of food. If there is a modern agricultural sector which produces food for the modern sector, or the availability of food imports, the development of this sector would not face possible restrictions of food supply from the traditional sector. However, if it is assumed that all agricultural production is in the traditional sector, all modern firms are in the industrial sector and have a closed economy, it is necessary to address the issue of how migrants acquire food if they transfer between sectors. In this scenario, the traditional agricultural sector has to supply food for the whole population. ${ }^{22}$ This had been made clear in Lewis (1954, p. 173):

${ }^{21}$ Since there was no distinction between the two different types of surplus labour in the previous literature, which of the two turning points is the Lewis turning point is ambiguous. Fei and Ranis (1997) refer to the second turning point as the Lewis turning point, but much of the literature refers to the first as the Lewis turning point instead. Therefore, in discussing the exhaustion of surplus labour, the types of surplus labour must be clarified, and in the discussion of an economy approaching the Lewis turning point, the specific turning point being referred to must also be clarified, since the wage patterns are totally different.

${ }^{22}$ The transfer of labour, constrained by the rate of food production (or marketable surplus), is the starting point for the original Jorgenson (1966) critique of the Lewis model, which argues that the growth of non-farm employment can be said to depend on the growth of the 
if we postulate that the capitalist sector is not producing food, we must either postulate that the subsistence sector is increasing its output, or else conclude that the expansion of the capitalist sector will be brought to an end through adverse terms of trade eating into profits.

However, this has to be examined more rigorously at the micro level. After all type I surplus labour has migrated, only those with a positive MPL remain in agriculture. As a result of this the per capita output share in the agricultural sector increases, although the average agriculture product for all the population, including migrants, stays unchanged. Now, those who moved out get food from the traditional sector. ${ }^{23}$ In this case, type I surplus labour would accept a wage of any level higher than zero in the modern sector, as subsistence is already provided and anything earned is net gain to the family. ${ }^{24}$ This means that labour would migrate at any positive wage, given the MPL in the agricultural sector is no higher than zero. Brown (2006, p. 352) argues that Lewis also 'believed individuals would still be willing to migrate, provided the family's combined income from both the traditional and modern sectors was higher than in the absence of migration' ${ }^{25}$

However, this is contrary to the argument that the minimum wage needed to induce migration should be no lower than the subsistence level. In Lewis's words:

... in economies where the majority of people are peasant farmers, working on their own land, we have a more objective index, for the minimum at which labour can be had is now set by the average product of the farmer; men will not leave the family farm to seek employment if the wage is worth less than they would be able to consume if they remained at home. (Lewis, 1954, pp. 148-149)

Theoretically, a marginally higher-than-zero wage can be true if, following migration to the modern sector, subsistence was assured. Practically, this may

agricultural surplus. The problem does not arise if productivity in agriculture is expanding rapidly, but Lewis himself recognized that the failure of peasant agriculture to increase its productivity has probably been the chief factor holding back the expansion of the industrial sector in many developing countries (Thirlwall, 2005, pp. 191-192). An example where the rural-to-urban migration was limited is Hayashi and Prescott (2008), in which they claim that in pre-war Japan per capita income was low because of a restriction on labour moving from the agricultural sector to the industrial sector. This resulted in surplus labour in agriculture but an inadequate supply in the industrial sector.

${ }^{23}$ Before migration, this type I surplus labour gets their share from agricultural production, whereas after migration food is provided by the family. With type I surplus labour there is no food problem as long as those remaining on the land do not increase their own consumption. However, this is a real possibility and a factor taken into account in the literature on shadow wage determination (e.g. Stiglitz, 1974).

${ }^{24}$ As Leeson (1979, p. 204) illustrates:

... when workers in mines and plantations continued to live in their subsistence sector homes and to derive many of their wage goods from the family provision. In this situation wages did not need to provide for the full maintenance of the labourer and yet might, though low, be acceptable as a net addition to the family income.

${ }^{25}$ It should be noted that this point by Brown is actually one of Lewis' contentions. Lewis is ambiguous on this issue when all his works are taken together. 
be unrealistic as it is more likely that, following Lewis' preceding argument, the lowest wage the modern sector offers should be no lower than the subsistence wage in the traditional sector. ${ }^{26}$

At the macro level, labour in the agricultural sector must be able to support the entire population. If technology and land supply is assumed fixed in the traditional sector, when the modern sector expands, surplus labour, first type I then type II, will gradually transfer out of the traditional sector.

When type I surplus labour moves out of the traditional sector, because their MPL in the traditional sector was zero or negative, total agriculture output will not fall. In aggregate terms, this sector is still able to provide enough food for the whole population. The migration of type I surplus labour will not add any pressure on the agricultural sector in terms of food supply. The modern sector can absorb as much type I surplus labour as it is willing and able to do.

Since the MPL of type I surplus labour in the traditional sector is zero or negative, this transfer is a net gain to the economy and there is no reason for the government to restrict migration. Clearly, if the modern sector does not have the ability to create sufficient employment opportunities, this transfer will have no growth effects and rather may result in urban tensions, which is why governments may erect barriers to labour movement.

In this case, the claim put forward by Fei and Ranis (1997, p. 51)-'Increases in agricultural productivity generating an agricultural surplus to sustain the workers in the non-agricultural sector is a prerequisite for the emergence of a non-agricultural sector and the expansion of its size'-is only true for type II surplus labour. The non-agricultural sector can emerge and expand so long as there is type I surplus labour in the traditional sector.

Because the MPL of type II surplus labour is positive, total food supply needs to be taken into consideration. Even if the modern sector has the ability to absorb more labour, if the agricultural sector is unable to provide enough food, further labour transfer would not be possible. If technology and land supply in the traditional sector are still constant, no transfer of type II surplus labour is possible, since any such transfer will lower total agriculture output. ${ }^{27}$ In this case, the increase in agricultural productivity becomes 'a prerequisite

\footnotetext{
${ }^{26}$ Stiglitz (1976) provides an efficiency wage hypothesis to solve this paradox. He implies that a wage that is below the subsistence level and only marginally different from zero is not practical. The modern sector would either leave a worker unemployed or employ them at the subsistence wage. However, in the framework of dual economy models, this difference can be ignored and it is typically assumed, without loss of generality, that the minimum wage in the modern sector should be no lower than the subsistence level. One way to think about this is to assume that the first 'unit' of a marginal increase of the wage above zero, when type I surplus labour migrates, involves an increase in the wage from zero to the subsistence level.

${ }^{27} \mathrm{As}$ discussed previously, there is an assumption that it is impossible for people to work harder and longer to make up for the loss of output resulting from this transfer.
} 
for the emergence of a non-agricultural sector and the expansion of its size'. The surplus generated from this can be 'used to permit both the allocation of more workers to non-agricultural activity and additional consumption of agricultural goods' (Fei and Ranis, 1997, p. 52). Thus:

Proposition 7: If technology and land supply in the traditional sector are constant, and thus total food supply is constant, there is no food constraint with the transfer of type I surplus labour; however, no transfer of type II surplus labour is possible.

Proposition 8: The transfer of type II surplus labour is possible only if agricultural technology improves and/or land supply increases, which increases productivity in the agricultural sector.

Proposition 9: The maximum rate of transfer of type II surplus labour is constrained by the rate of food increase generated by technical change and/or the rate of land supply increases in the traditional sector.

The above analysis is for a real economy without money although introducing money and prices to show the mechanisms of exchange is not difficult. The expansion of the modern sector will shift the terms of trade in favour of agricultural goods and labour from the agricultural sector will become more expensive. If there was insufficient food in the economy and if labour were to try to move out, the price of food would become infinitely high. No labour transfer would therefore be possible. When technology improves, less labour is needed to produce the same output, the food price drops and labour transfer becomes possible again.

\section{Dynamics of Surplus Labour}

As discussed above, the transfer of type II surplus labour is possible only if agricultural productivity improves. Throughout history agricultural technology has improved and so too has the marginal product of labour. Because the MPL is the benchmark in measuring surplus labour, technical change in the traditional agricultural sector changes the amount of surplus labour in that sector. This allows dynamics to be introduced into the model.

Proposition 10: In the absence of labour transfer, the increase of the agricultural total factor productivity (TFP) will create more surplus labour (both type I and type II) in the traditional sector.

Proposition 11: If the rate of emigration is in line with the rate of TFP increase in the traditional sector, the total amount of surplus labour will be 
constant in the traditional sector; if the rate of TFP increase is quicker than the rate of transfer, the total amount of surplus labour will increase.

As discussed above, when surplus labour is constant or increasing, the wage will not increase, and the modern sector will have an unlimited supply of labour from the traditional sector at a constant wage level. For example, because type I surplus labour is the overall amount of labour not required for existing production, technical change that improves efficiency will increase the total surplus labour.

From the neoclassical perspective, Proposition 10 sounds counterintuitive, since with technological change labour has a higher MPL and APL, so surplus labour falls in the sense of MPL $<w_{s}$. However, this argument cannot be applied directly as surplus labour is measured by the extent of the oversupply with respect to a given output. Technical change, such as laboursaving technologies and the impact of the Green Revolution, improves productivity and the MPL increases and, consequently, the oversupply increases. It must be stressed that technical change increases the MPL of those labourers already employed but not the entire labour force. The MPL of surplus labour is now lower if they participate in production. In the estimation and prediction of the extent of surplus labour, and in the calculation of a date for the turning point, this dynamic effect needs to be taken into consideration.

\section{Dynamics of Labour Transfer}

There are two driving forces that determine the amount of surplus labour and affect the transfer of labour from the traditional to the modern sector. On the supply side, the MPL, the APL and the rate of technical change in the traditional sector all determine the amount of labour that can be released. On the demand side, the rate of modern sector expansion and its absorptive capacity determines its ability to create employment. ${ }^{28}$

The transition dynamics of the transfer of labour to the modern sector can be shown in a figure. Figure 2 is a modified version of the bottom half of Fig. 1 where $\bar{P}$ is replaced by $O^{\prime}$. The horizontal axis, $O O^{\prime}$, is the total population in the economy. The traditional sector labour is to the right of the origin $O$. The modern sector labour is to the left of $O^{\prime}$. The MPL $\mathrm{A}_{\mathrm{A}}$ and $\mathrm{APL}_{\mathrm{A}}$ curves are the marginal and average product of labour in the traditional agricultural sector, as in Fig. 1. The MPL ${ }_{I}$ curve is the marginal product of labour in the modern industrial sector. $\mathrm{MPL}_{\mathrm{I}}^{\prime}, \mathrm{MPL}_{\mathrm{I}}^{\prime \prime}$ and $\mathrm{MPL}_{\mathrm{I}}^{\prime \prime \prime}$ represent different stages of industrial development. ${ }^{29}$

\footnotetext{
${ }^{28} \mathrm{How}$ much the modern sector expands in output and/or employment depends on the nature of technological change, the division of labour, the demand for its output and its terms of trade with respect to the traditional sector.

${ }^{29}$ For ease of illustration the three $\mathrm{MPL}_{\mathrm{I}}$ curves are drawn as straight lines.
} 


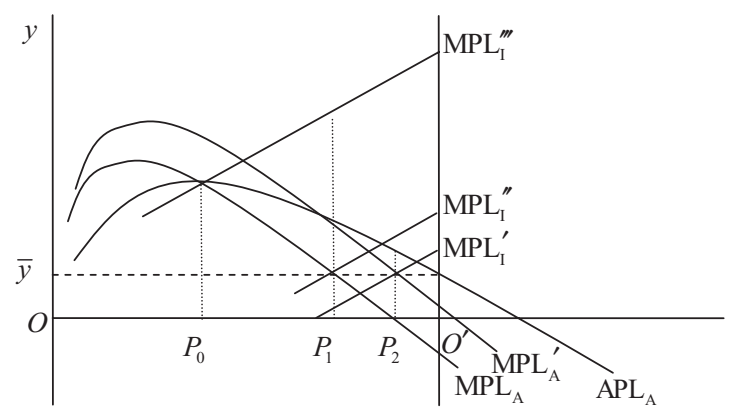

FIG. 2. Dynamics of Labour Transfer

The question of why and how the modern industrial sector emerges is beyond the scope of this paper. Here it is simply assumed that it is small at the beginning and requires some labour which it is able to take from the pool of surplus labour in the traditional agricultural sector. Up to $\mathrm{MPL}_{\mathrm{I}}^{\prime}$, all labour transferred is type I surplus labour. Their marginal product in agriculture is zero or negative, but when they transfer to the modern sector, their marginal product becomes positive. Although wages are still at subsistence level, this is a net contribution to the economy and a Pareto gain is made from this transfer.

When type I surplus labour is transferred out of the traditional agricultural sector, the average product of labour in agriculture will rise. This will cause a population increase, and $O^{\prime}$ will be moved further to the right, until again the $\mathrm{APL}_{\mathrm{A}}=\bar{y}$ is reached. This will not affect productivity in the modern industrial sector, but the agricultural sector will absorb all the increased population. ${ }^{30}$ That is, the population growth will replace labour that has transferred and the same level of surplus labour will exist at the same level of per capita income.

In Fig. 2, the rate of growth of employment in the modern industrial sector is the speed of the shift of the MPL to the left. If this is slower than the move of $O^{\prime}$ to the right this means that the migration rate is smaller than the rate of population growth in the traditional sector. In this case, the agricultural sector will always have surplus labour, and the industrial sector always pays a subsistence wage for this labour. If industry grows faster than the population growth, i.e. the speed of the shift of $M P L_{I}$ is greater than the speed of the move of $O^{\prime}$ to the right, then the share of population in the agricultural sector will fall and that in industry will increase.

If the move of MPL in the horizontal direction on the figure is defined as the difference between the number of migrants and the rise in population, then the change in population can, for simplicity, be ignored in this discussion. As industry expands, MPL $\mathrm{L}_{\mathrm{I}}$ moves upwards and to the left as migration

${ }^{30}$ It is in this sense that the agricultural sector is known as the sink for surplus labour. 
increases until $\mathrm{MPL}_{\mathrm{I}}^{\prime}$ is reached, at which point type I surplus labour is exhausted in the agricultural sector. Before this point, the transfer only depends on the absorptive capacity of the industrial sector and the supply of agricultural output is not a constraint. When industry expands further beyond $\mathrm{MPL}_{\mathrm{I}}^{\prime}$, the marginal product of labour in the agricultural sector becomes positive although still lower than the subsistence wage. Between $M P L_{I}^{\prime}$ and $M P L_{I}^{\prime \prime}$ there is type II surplus labour transferring out of agriculture. This will not only be determined by the growth of the industrial sector, but also by the development of the agricultural sector. The transfer will not be possible, because if people with positive marginal product of labour transfer out, the total output and average output of agricultural goods will drop below subsistence level. The necessary condition for type II surplus labour to be transferred out is for technological change in the agricultural sector to increase the marginal product of the remaining labour, making them able to produce sufficient output for both sectors. This is where the role of agriculture becomes important, as discussed in the previous section. In the figure, the $\mathrm{MPL}_{\mathrm{A}}$ has to shift upwards and to the right to a new curve, $M P L_{\mathrm{A}}^{\prime}$. The wage that the industrial sector offers should not be lower than the subsistence level plus their original marginal product. So now, the industrial sector wage for type II surplus labour has to be higher than the subsistence level as this was type II surplus labour in the agricultural sector before technological change. Without faster expansion of the industrial sector, labour would stay in agriculture and become type I surplus labour. But now, with the joint forces from industrial sector expansion and agricultural technological improvements in the traditional sector, they change from the original type II surplus labour to a competitive labour force. After this point, the labour market becomes competitive, the industrial sector has to pay higher wages than the subsistence level, with the wages determined by the intersections of the MPL $L_{I}$ and the MPL .

\section{Conclusions}

For economies in the early stages of development, the traditional agricultural sector consists of family farming units. Family members work together and share the result of their labour. Wages are equal to the average rather than the marginal product of labour. Thus, it is possible that surplus labour exists. Given this surplus labour in the traditional sector, the modern sector can expand without increasing labour costs. This process will continue until the surplus labour in the traditional sector is exhausted. Then wages begin to rise consistent with rising marginal productivity, in which labour in the traditional sector is paid at the level of their marginal product rather than the subsistence wage. At this stage, the dualistic economic structure disappears, replaced by a competitive one-sector economy that can be explained by the neoclassical model. 
This paper contributes to the literature by clarifying some of the ambiguities in the discussions related to the Lewis model. There has long been a debate about the precise definition of surplus labour. This paper first identified the problem and defined two types of surplus labour: type I (absolute) when the marginal product of labour is equal to or even lower than zero, and type II (relative) when the marginal product of labour is higher than zero but lower than the wage level, which is set at the subsistence level in the long run. This seemingly simple distinction resolves much of the misunderstanding. Based on this classification of two types of surplus labour, two turning points are defined: the type I is when type I surplus labour is used up; and type II, when type II surplus labour is used up. The wage is constant before the type I turning point, increases slowly after it, and the dual economy becomes a one-sector economy after the type II turning point is passed.

Another major debating point in the literature is how the wage in the modern sector is determined. There are two mutually contradictory mechanisms here, and many authors including Lewis have been ambiguous in this regard. The latest debate is between Brown (2006) and Fields (2004, 2006), 52 years after the publication of the Lewis (1954) paper. This paper defines two mechanisms. Wage Determination Mechanism I states that the real wage in the modern sector is determined by the real wage in the traditional sector and anything that raises the productivity of the traditional sector will raise real wages in the modern sector. Wage Determination Mechanism II states that the modern sector wage is set independently of that in the traditional sector, by a combination of institutional forces that could include unions, a minimum wage and public sector pay policy. With these definitions, several propositions are offered to address these problems. The conclusion is that there is unlimited absolute surplus labour under Wage Determination Mechanism I only if the population growth can replace labour that has been withdrawn. Under Wage Determination Mechanism II, if the modern equilibrium wage equals the traditional sector wage, no labour market segmentation condition is needed; if the modern equilibrium wage is higher than the traditional sector wage, market segmentation measures such as restrictions on entry are needed to maintain higher wages in the modern sector.

This paper also takes the issue of food supply from the agricultural sector into account in the study of labour transfer. If the agricultural sector is identical to the traditional sector, total agricultural output will not reduce and may even increase when type I surplus labour is transferred out. However, when type II surplus labour is transferred out, there is an aggregate food supply problem. Without technological change or an increase in the area of cultivated land, this kind of transfer is not possible.

When technical change in the traditional sector is taken into account, surplus labour becomes dynamic. If the rate of transferring surplus labour away from the traditional sector is in line with the rate of TFP increase, the total amount of surplus labour is constant; if the rate of TFP increase is 
greater than the rate of transfer, the total amount of surplus labour will increase. These dynamics are of great importance for empirical studies that estimate and predict the quantity of surplus labour that exists at any given point in time.

\section{REFERENCES}

Brown, R. (2006). 'On Labour Market Dualism in the Lewis Model: a Comment', The Manchester School, Vol. 74, No. 3, pp. 350-354.

Colman, D. and Nixson, F. (1994). Economics of Change in Less Developed Countries, London, Harvester Wheatsheaf.

Fei, J. C. H. and Ranis, G. (1964). Development of the Labor Surplus Economy: Theory and Policy, Homewood, IL, Richard A. Irwin.

Fei, J. C. H. and Ranis, G. (1997). Growth and Development from an Evolutionary Perspective, Oxford, Blackwell.

Fields, G. S. (2004). 'Dualism in the Labor Market: a Perspective on the Lewis Model after Half a Century', The Manchester School, Vol. 72, No. 6, pp. 724-735.

Fields, G. S. (2006). 'Labour Market Dualism in the Lewis Model: Reply', The Manchester School, Vol. 74, No. 3, pp. 355-359.

Findlay, R. (1980). 'On W. Arthur Lewis's Contribution to Economics', Scandinavian Journal of Economics, Vol. 82, No. 1, pp. 62-76.

Harris, J. R. and Todaro, M. P. (1970). 'Migration, Unemployment and Development: a Two-sector Analysis', American Economic Review, Vol. 60, No. 1, pp. 126-142.

Hayashi, F. and Prescott, E. C. (2008). 'The Depressing Effect of Agricultural Institutions on the Prewar Japanese Economy', Journal of Political Economy, Vol. 116, No. 4, pp. 573-632.

Jorgenson, D. W. (1961). 'The Development of a Dual Economy', Economic Journal, Vol. 71, No. 282, pp. 309-334.

Jorgenson, D. W. (1966). 'Testing Alternative Theories of the Development of a Dual Economy', in I. Adelman and E. Thorbecke (eds.), The Theory and Design of Economic Development, Baltimore, MD, John Hopkins University Press, pp. 45-60.

Kirkpatrick, C. and Barrientos, A. (2004). 'The Lewis Model after 50 Years', The Manchester School, Vol. 72, No. 6, pp. 679-690.

Kremer, M. (1993). 'Population Growth and Technological Change: One Million B.C. to 1990', Quarterly Journal of Economics, Vol. 108, No. 3, pp. 681-716.

Leeson, P. (1979). 'The Lewis Model and Development Theory', The Manchester School, Vol. 47, No. 3, pp. 196-210.

Leeson, P. (2008). 'On Models of Development', Unpublished Manuscripts, The University of Manchester.

Lewis, W. A. (1954). 'Economic Development with Unlimited Supplies of Labour', The Manchester School, Vol. 28, No. 2, pp. 139-191.

Lewis, W. A. (1972). 'Reflections on Unlimited Labour', in L. E. diMarco (ed.), International Economics and Development (Essays in Honour of Raoul Prebisch), New York, Academic Press, pp. 75-96.

Lewis, W. A. (1979). 'The Dual Economy Revisited', The Manchester School, Vol. 47, No. 3, pp. 211-229.

Malthus, T. (1798). An Essay on the Principle of Population. London, J. Johnson, in St Paul's Churchyard.

Ranis, G. (2008). 'Labour Surplus Economics', in S. N. Durlauf and L. E. Blume (eds.), The New Palgrave Dictionary of Economics, 2nd ed., Basingstoke, Palgrave Macmillan. 
Sen, A. K. (1966). 'Peasants and Dualism with or without Surplus Labour', Journal of Political Economy, Vol. 74, No. 5, pp. 425-450.

Sen, A. K. (1967). 'Surplus Labor in India: a Critique of Schultz' Statistical Test', Economic Journal, Vol. 77, No. 305, pp. 154-161.

Stiglitz, J. E. (1974). 'Alternative Theories of Wage Determination and Unemployment in LDCs: the Labour Turnover Model', Quarterly Journal of Economics, Vol. 88, No. 2, pp. 194-227.

Stiglitz, J. E. (1976). 'The Efficiency Wage Hypothesis, Surplus Labor, and the Distribution of Labour in LDCs', Oxford Economic Papers, Vol. 28, No. 2, pp. 185-207.

Temple, J. (2005). 'Dual Economy Models: a Primer for Growth Economists', The Manchester School, Vol. 73, No. 4, pp. 435-478.

Thirlwall, A. P. (2005). Growth and Development: with Special Reference to Developing Economies, 8th edn, London, Palgrave Macmillan.

Todaro, M. P. (1969). 'A Model of Labour Migration and Urban Unemployment in Less Developed Countries', American Economic Review, Vol. 59, No. 1, pp. $138-148$.

Wellisz, S. (1968). 'Dual Economies, Disguised Unemployment and the Unlimited Supply of Labour', Economica, New Series, Vol. 35, No. 137, pp. $22-51$. 